\title{
Division of labour and communication at the individual level in highly social Formica ants (Hymenoptera: Formicidae)
}

\author{
Разделение труда и коммуникаџия на индивидуальном уровне \\ у высоко сощиальных видов муравьев рода Formica \\ (Hymenoptera: Formicidae)
}

\author{
Zh.I. Reznikova \\ Ж.И. Резникова
}

Institute of Systematics and Ecology of Animals, Siberian Branch of the Russian Academy of Sciences and Novosibirsk State University. E-mail: zhanna@reznikova.net

Институт систематики и экологии животных СО РАН и Новосибирский государственный университет.

KEY WORDS: Formica, division of labour, recruitment, communication, learning, behavioural syndrome, aphid tending, individual recognition.

КЛЮЧЕВЫЕ СЛОВА: Formica, разделение труда, мобилизация, коммуникация, обучение, поведенческий синдром, уход за тлями, индивидуальное распознавание.

ABSTRACT. In this mini-review, division of labour and communication in highly social Formica species are considered at the individual level. Group-retrieving Formica species enjoy flexible and rational communication based on task allocation between scouts and foragers within small stable working teams. Scouts are able to memorise and pass "abstract" information to foragers, in particular, the information about a sequence of turns on the way to a feeder, whereas foragers are not able to transmit information. A field model of the situation in which ants act collectively to perform a specific task could be the organisation of honeydew collection in the tree crown. In $F$. polyctena, groups of aphid tenders include members of different "professions" (shepherds, guards, transporters and scouts) which stay in stable cohesion for a few weeks.

РЕЗЮМЕ. В кратком обзоре рассматриваются разделение труда и коммуникация на индивдуальном уровне у высоко социальных видов рода Formica. В многолетних лабораторных опытах показано, что виды рода Formica с групповой системой фуражировки обладают гибкой и рациональной коммуникацией, основанной на разделении ролей между разведчиками и фуражирами в небольших, стабильных по составу, рабочих группах. Разведчики способны запомнить и передать фуражирам "абстрактную" информацию, в частности, сведения о последовательности поворотов на пути к кормушке; фуражиры воспринимают и запоминают "сообщения”, но не передают их. В естественных условиях ситуация, в которой муравьи действуют группой, выполняя сообща определенную задачу - это организация сбора пади на колониях тлей в кроне дерева. Показано, что у $F$. polyctena группы сбор- щиков пади стабильны по составу и включают членов разных "профессий” (пастухи, охранники, транспортировщики и разведчики), которые работают вместе в течение нескольких недель.

\section{Introduction}

There are about twelve thousand ant species in the world fauna that vary enormously in their colony size, degree of polygyny and polyandry, in temporal and physical caste structure, in forms of territorial organization, foraging systems, communications, and in flexibility and complexity of their behaviour. Collectively foraging ants represent the behavioural "mainstream" among the whole range of ant species (see reviews in [Hölldobler, Wilson, 1990, 2008]). Their foraging system is mainly based on mass recruitment. In some species colony success is likely to depend on the division of labour between members of morphologically distinct sub-castes of the worker caste [Oster, Wilson, 1978; Schmid-Hempel, 1992]. In many species, members of a colony can differ behaviourally but not morphologically. The "swarm intelligence" concept is applicable to all these species, by which patterns of interactions among individuals are governed by rules of self-organisation, and fairly simple units generate complicated behaviour of the group as a whole [Dornhaus, 2008; Chittka, Muller, 2009; Gordon, 2010]. However, learning and flexible behaviour play an essential role in the capacity of those species for exploitation of new food sources [Dlussky et al., 1978; Reznikova, Panteleeva, 2008]. In solely foraging species, individual colony members are more agile and they learn faster than members of mass recruitment species [Reznikova, 1982]. 


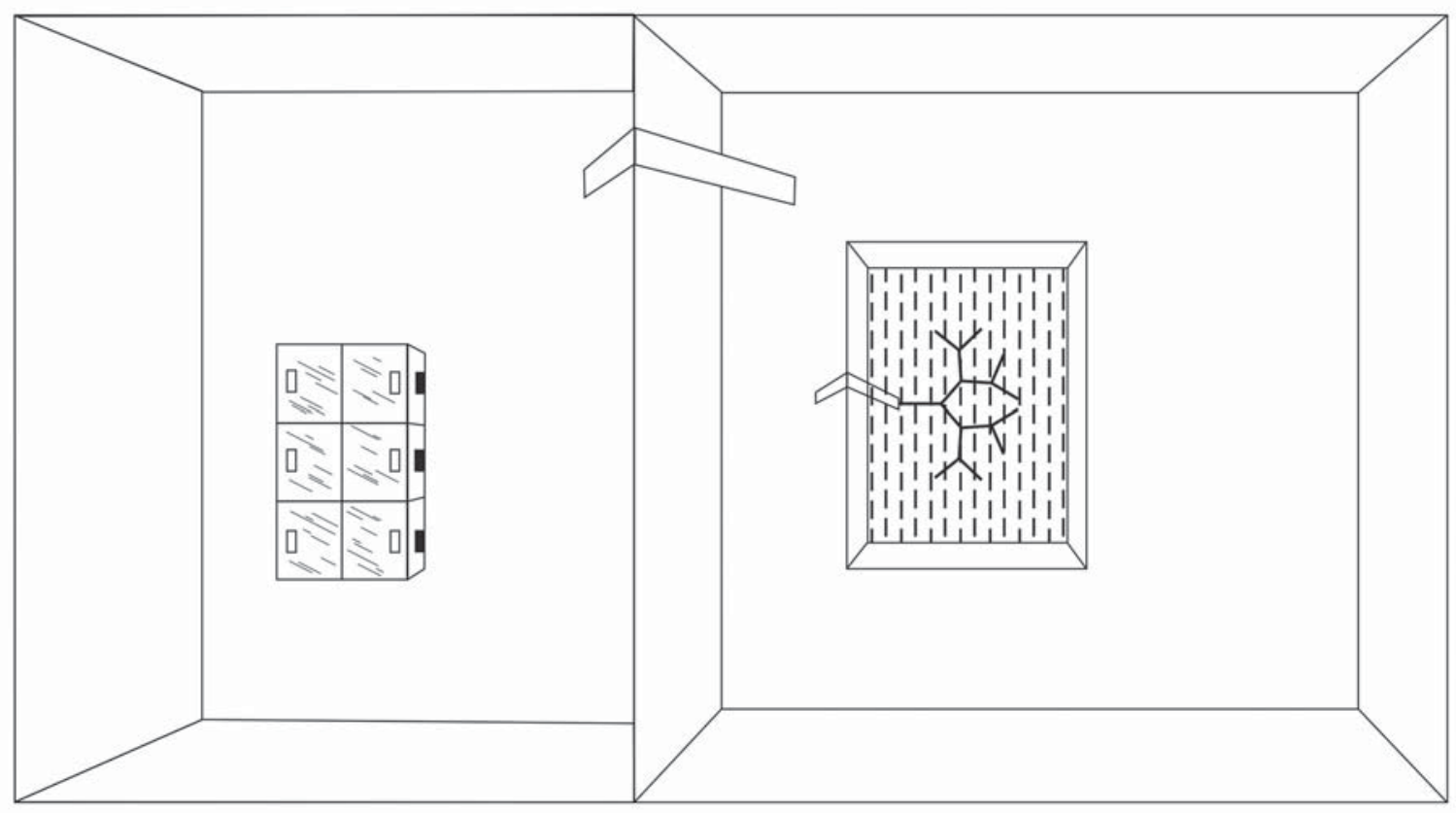

Fig. 1. The laboratory arena with a "binary tree" maze.

Group-retrieving Formica species (especially those of the Formica rufa Linnaeus, 1758 group) are probably the most promising group for studying the division of labour and communication at the individual level. There are many tasks in their routine activities that require working in stable teams and demand complex communication. For example, in order to obtain honeydew, red wood ants have to find and possibly memorise and pass to others locations of thousands of aphid colonies within a huge three-dimensional space, i.e. a tree. To treat their spacious feeding territories, red wood ants have to use intermediate stations for contacts between scouting and foraging individuals [Dlussky, 1965], and perhaps the most efficient means of communication in this case is distant homing, that is, transferring "messages" about remote events without other cues, like scent trails or direct guiding [Reznikova, 2007, 2008].

Although the F. rufa group is one of those at the centre of myrmecological studies [Rasnitsyn, Quicke, 2002], for a long time amazingly little was known about the organization of group foraging and information transfer at the individual level in these species.

\section{Information transfer based on distant hom-} ing in ant working teams

Experimental evidence of individual task allocation between members of working teams within a colony of group-retrieving Formica species first came from investigations of information transmission by distant homing with the use of the "binary tree" paradigm suggest- ed by Zh. Reznikova and B. Ryabko [1986, 1994]. This experimental paradigm simulates a natural situation that requires distant homing. The use of the "binary tree" paradigm demonstrated that red wood ants Formica polyctena Förster, 1850 and ecologically similar F. sanguinea Latreille, 1798 are able to transfer information about sequences of turns on the way to a feeder that was situated on one of the leaves of a maze called "binary tree".

The goal of this study was to investigate ants" "language behaviour", that is, their capacity of transferring "abstract" messages by means of distant homing. However, another important result is that the sophisticated system of information transmission in group-retrieving Formica is based on individual inter-relations within teams that remain stable for several days and even weeks [Reznikova, 2008]. The "binary tree" experimental paradigm presents a situation when ants have to transmit information about the sequence of turns towards a trough with syrup in order to obtain food. In the "binary tree" maze each "leaf" ends with an empty trough with the exception of the only one filled with syrup. The simplest design is a tree with two leaves, that is, a Y-shaped maze. In this situation the information possibly transmitted by a scouting ant to other individuals is: to go to the right $(\mathrm{R})$ or to the left $(\mathrm{L})$. In other experiments the number of forks of the binary tree increased to six (three in Fig. 1). Ants lived in the laboratory arena, in a transparent nest that made it possible for their activity to be observed. The arena was divided into two sections: a smaller one containing the nest, and a bigger one with an experimental system (Fig. 1). The two sections were interconnected with a 
Table 1. Visits to the maze by different teams of Formica sanguinea.

Таблица 1. Посещение лабиринта различными группами Formica sanguinea.

\begin{tabular}{|l|l|}
\hline $\begin{array}{l}\text { Team index (symbols } \\
\text { of teams correspond to } \\
\text { symbols of scouts) }\end{array}$ & $\begin{array}{l}\text { Number of days after the start } \\
\text { of the main experiment }\end{array}$ \\
\hline I & $1,3,5,7,9,11,19$ \\
\hline II & $1,3,5,7,9,11,19,21,30,34$ \\
\hline III & $3,5,7,9,11,19,21,23,30$ \\
\hline IV & $3,7,9,11,13,15,19,23,30,34,40$ \\
\hline V & $1,3,5,7,9,11,23,32$ \\
\hline VI & $1,3,9,13,19,21,23,25,32,37$ \\
\hline VII & $7,9,11,21,23,32,34$ \\
\hline VIII & $7,9,11,13,19,21,25,45$ \\
\hline IX & $19,23,25,27,29,34,37$ \\
\hline X & $19,25,29,32,34,37,40,42,45$ \\
\hline XI & $13,29,34$ \\
\hline XII & $21,32,34,37,40,42$ \\
\hline XIII & $27,32,37,42,45$ \\
\hline XIV & $32,37,42,45$ \\
\hline XV & 45 \\
\hline
\end{tabular}

bridge that was removed at times to modify the set-up or isolate the ants. To prevent access to the food in the maze by a straight path, the set-up was placed in a bath of water, and the ants reached the initial point of the binary tree by going over a second small bridge. In different years three colonies of $F$. polyctena and two of $F$. sanguinea used in the experiments consisted of about 2000 individuals each. All foraging ants were individually marked with coloured paint during the preliminary stage of the experiments (see details in [Reznikova, 2008]).

The laboratory colonies were found to include teams of constant membership which consisted of one scout and three to eight foragers: the scout mobilised only members of its team to the food. In total, 335 scouts along with their teams were used in all experiments with the binary tree. In each trial, one of the scouts that were actively moving on the experimental arena at that moment was placed on a leaf of the binary tree that contained a trough with the food, and then it returned to the nest by itself. All experiments were so devised as to eliminate all possible cues that could help the ants to find the food, except information contact with the scout. During each series of experiments with the trough placed on the next leaf of the binary tree, all teams that were active on that day worked successively. While the trial was going on, the bridge leading to the working part of the arena was taken away, in order not to let members of other teams move there. While the scout was inside the nest, the whole maze was replaced by a fresh one with all troughs empty. After the scout had contacted its team, it was isolated for a while, and the foragers had to search for the food by themselves. Foragers were presented with the syrup if they reached the correct leaf of the binary tree. The process of information transmission has been described in the papers about the “ant language" [Ryabko, Reznikova, 1996, 2009]. It is worth noting that the composition of the working teams remained constant in each colony from several days to several weeks, that is, during periods when a given scout was actively working. The number of days since the start of the main experiment when each of 13 scouts appeared on the maze (and then attracted its team) is given in Table 1 (published here for the first time). This is a single series of experiments with one of two colonies of $F$. sanguinea, as an example of stability of teams. Different scouts visited the maze from 1 to 11 out of 20 experimental days of the presented series of experiments. The duration of the presented series of experiments was 45 days, and the experiments were conducted every 2 or 3 days. It is noteworthy that, although each "visiting day" is presented in Table 1 only once per team, the scout (and its team) could visit the maze from one to four times a day (see [Reznikova, Ryabko, 1994]).

Special experiments revealed that foragers, apart from scouts, were unable to transmit information. The evidence of information transmission from the scouts to the foragers came from two sets of data: first, from statistical analysis of the number of faultless findings of the goal by a group, and second, from a special series of control experiments with "uninformed" ("naive") and "informed" foragers. It is particularly important that scouts can not only transfer the exact information about the location of the goal, but they can also grasp regularities and use them to optimise and shorten their messages. For example, they spent half the time for transferring the information about "regular" sequences of turns, such as «LLLLLL» or «LRLRLR» (that is, six times to the left", or "three times left right"), as compared to shorter but "random" sequences such as "RLLRL" (see details in [Reznikova, 2008; Ryabko, Reznikova, 1996]). These results enable us to suggest that scouting ants can use rule extraction in order to optimise their messages.

There is strong evidence from the "binary tree" study that working in teams is based on intricate process of inter-relations between scouts and foragers. $\mathrm{Zh}$. Reznikova and T. Novgorodova [1998a] observed the ontogenetic trajectories of 80 newly hatched red wood ants in a laboratory colony of $F$. sanguinea and watched the process of shaping teams. There were 16 working teams in that colony which mastered mazes. From 80 individually marked naive ants, 17 entered 7 different working teams, 1 to 4 individuals in each. Only three became scouts, two of them starting as foragers joining two different teams and one starting as a scout at once. The three new groups were composed of workers of different age that were not engaged in any groups and possibly served as "reservists". The age at which the ants were capable to take part in the working groups as foragers ranged from 18 to 30 days, and the ants could become scouts at the age of 28 to 36 days. Constancy of membership was examined in two colonies of $F$. sanguinea and $F$. polyctena. All team members were isolated from nine scouts. As a result, three scouts 
appeared to mobilise their previous acquaintances and attract new foragers, four scouts were working solely, and two scouts of $F$. polyctena ceased to appear on the arenas. In another experiment with $F$. polyctena, scouts were removed from five teams. It was possible to see foragers from those groups on the arenas without their scouts. 15 times different foragers were placed on the trough with the food, but after their coming back home they contacted other ants only rarely and occasionally.

Task allocation and professional specialisation in ant working teams in nature

A field model of the situation in which ants act collectively to perform a specific task could be the organisation of honeydew collection in the tree crown. Indeed, the very idea to examine sophisticated division of labour in teams of aphid milkers stems from the "binary tree" study [Reznikova, Ryabko, 1986, 1994]. In a natural situation the task is to find an aphid colony, inform other ants about the new food source, and organise honeydew collection and transportation [Mordvilko, 1901; Way, 1963; Völkl et al., 1999]. Reznikova and Novgorodova [1996, 1998a] were the first to describe the system of intricate division of labour (professional specialisation) in groups of aphid tenders working on separate aphid colonies. It turned out that in species of the Formica rufa group that exhibited the recruitment system based on distant homing, each aphid colony is attended by a constant group of individuals (a team) which perform different tasks and possibly recognise each other personally.

The study of professional specialisation within teams of aphid milkers is based on observations on 350 individually marked ants which were working in distinct groups on 13 aphid colonies. Each aphid colony with working ants was monitored from 20 to 35 hours (300 hours in total). Individual labels were kept on ants for up to 47 days. Analysing ethograms, the authors singled out 12 behavioural patterns: (1) contacts with aphids and honeydew collection, (2) standing still, (3) allogrooming, (4) trophallaxis (food exchange between ants), (5) antennal contacts between ants, (6) alerted posture with open mandibles and stretched antennae, (7) demonstrative aggressive posture, ready to splash acid, (8) attacks towards strangers (including ants), (9) abrupt jogging around the aphid colony, (10) exploratory activity in the vicinity of the aphid colony, (11) transporting food to the nest, (12) going across to another aphid colony. All ants exhibited strong attachment to certain aphid colonies during the whole period of observation (three weeks on average), and members of each group worked together permanently. Although all twelve behavioural patterns appeared to be universal for all aphid tenders, ants differed essentially by the proportion of different patterns in their behavioural repertoire. The cluster analysis of individual ethograms revealed the following strongly stable professional

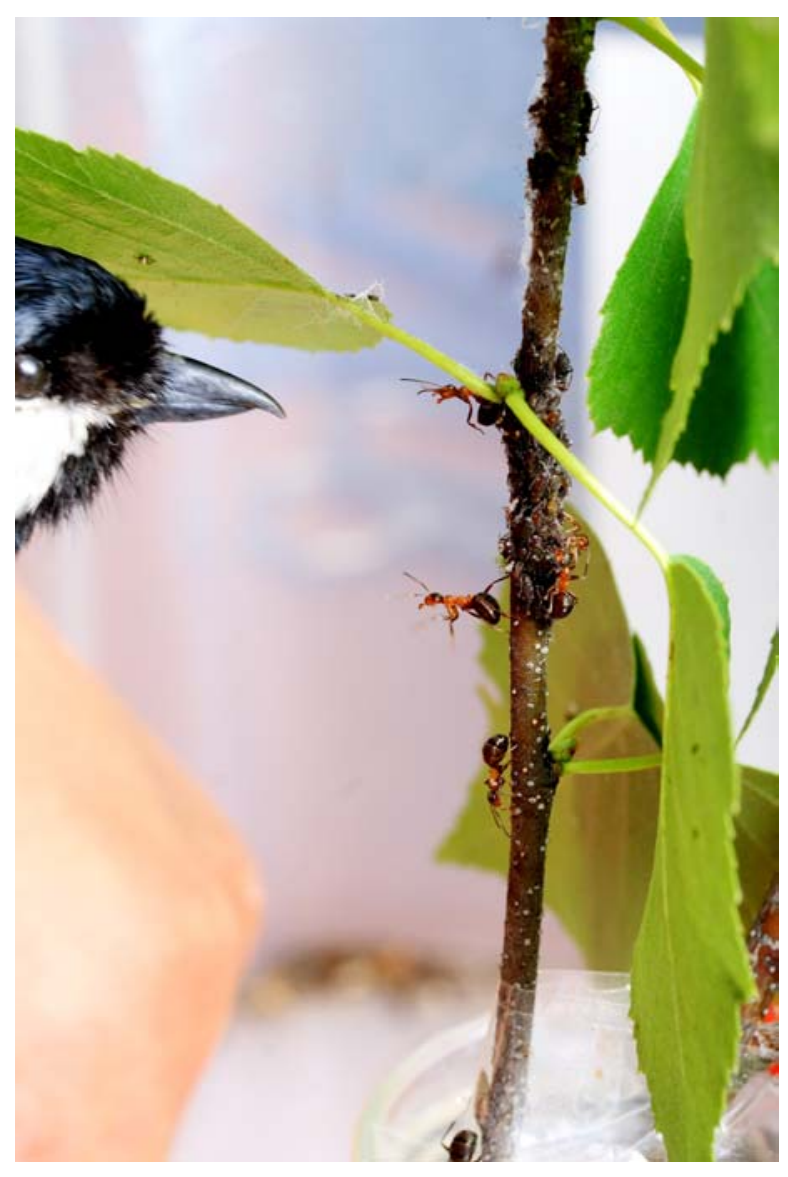

Fig. 2. Two guards react aggressively to a stuffed blue tit, while a full transporter quietly walks down a twig, and a shepherd continues milking an aphid.

groups: "shepherds" only look after aphids and milk them, "guards" only guard the aphid colony and protect it from external factors, "transporting" ants transfer the food to the nest, and "scouts" search for the new colonies.

A professional specialisation of that kind increases the efficiency of trophobiosis between ants and aphids. When ants were experimentally forced to change their roles, much food was lost. Although ants can improve their professional skills, ontogenetic study revealed that the main behavioural patterns characteristic of aphid tending are innate in ants, and they only demand maturation but not experience [Reznikova, Novgorodova, 1998b; Reznikova, Iakovlev, 2008]. However, members of each professional group possess a stable set of behavioural features (see Fig. 2). This can be considered a "behavioural syndrome", that is, a suite of correlated behaviours across different contexts and situations. This phenomenon was firstly described in vertebrates [Sih et al., 2004], and have been only partially applied to insects [Kortet, Hedrick, 2007]. 


\section{Conclusion}

Long-term laboratory experiments revealed complex communication system in $F$. polyctena and $F$. sanguinea based on sophisticated division of labour between scouts and foragers within stable working teams. Scouts are able to memorise and pass "abstract" information to foragers in their working teams by means of distant homing, in particular, information about sequence of turns on the way to a feeder, whereas foragers are not able to transmit information. Each scout shares information on the discovered food only with its own small group of foragers. Formation of teams is apparently a complex process which is based on intricate long-term relations between scouts and foragers developed at early stages of imaginal ontogenesis.

A field model of the situation in which ants act collectively to perform a specific task is the organisation of honeydew collection by aphid milkers in the tree crown. In $F$. polyctena, groups of aphid tenders include members of different "professions" (shepherds, guards, transporters and scouts) which stay in stable cohesion for a few weeks. Ants belonging to different professions possess stable sets of distinct behavioural features that can be considered a "behavioural syndrome".

\section{ACKNOWLEDGEMENTS}

This study was supported by the grant No. 11-0400536-a from the Russian Foundation for Basic Research, by the grant No. 26.6 from the "Biological Diversity" Program of the Presidium of the Russian Academy of Sciences, and by the Project No. 112 of the Program of Integrative Projects of Siberian Branch of the Russian Academy of Sciences.

\section{References}

Chittka L., Muller H. 2009. Learning, specialization, efficiency and task allocation in social insects // Communicative and Integrative Biology. Vol.2. P.151-154.

Dlussky G. M. 1965. [Protected territory of ants] // Zhurnal Obshchei Biologii. Vol.26. P.479-489 [in Russian with English abstract].

Dlussky G.M., Voltsit O.V., Sulkhanov A.V. 1978. [Organization of group foraging in ants of the genus Myrmica] // Zoologichesky Zhurnal. Vol.57. P.65-77 [in Russian with English abstract].

Dornhaus A. 2008. Specialization does not predict individual efficiency in an ant // PLoS Biology. Vol.6. No.11. P.2368 - 2375.

Gordon D.M. 2010. Ant Encounters: Interaction Networks and Colony Behavior. Princeton University Press. 168 pp.

Hölldobler B., Wilson E.O. 1990. The ants. Cambridge: The Belknap Press of Harward University Press. 752 pp.
Hölldobler B., Wilson E.O. 2008. The Superorganism: The beauty, elegance, and strangeness of insect societies. New York: W.W. Norton. 522 pp.

Kortet R., Hedrick A. 2007. A behavioural syndrome in the field cricket Gryllus integer : intrasexual aggression is correlated with activity in a novel environment // Biological Journal of the Linnean Society. Vol.91. P.475-482.

Mordvilko A.K. 1901. [Biology and morphology of aphids] // Trudy Russkogo Entomologicheskogo Obshchestva. Vol.33. P.418-475 [in Russian].

Novgorodova T.A., Reznikova Zh.I. 1996. Ecological aspects of interaction between ants and aphids in the forest park zone of the Novosibirsk Scientific Centre // Siberian Journal of Ecology. Vol.3-4. P.239-245.

Oster G.F., Wilson E.O. 1978. Caste and ecology in the social insects. Princeton: Princeton University Press. 352 pp.

Rasnitsyn A.P., Quicke D.L.J. (eds). 2002. History of Insects. Dordrecht, Boston, London: Kluwer Academic Publishers. 517 pp.

Reznikova J. (Zh). 1982. Interspecific communication among ants // Behaviour. Vol.80. No.1-2. P.84-95.

Reznikova Zh. 2007. Animal Intelligence: From Individual to Social Cognition. Cambridge: Cambridge University Press. 472 pp.

Reznikova Zh.I. 2008. Experimental paradigms for studying cognition and communication in ants (Hymenoptera: Formicidae) // Myrmecological News. Vol.11. P.201-214.

Reznikova Zh.I., Iakovlev I.K. 2008. Development of aggression as a possible basis of "professional specialisation" in ants // Doklady RAS. Biological Sciences. Vol.418. P.56-58.

Reznikova Zh.I., Novgorodova T.A. 1998a. [Division of labour and exchange of information within ant settlement] // Uspekhi Sovremennoi Biologii. Vol.118. No.3. P.345-357 [in Russian with English abstract].

Reznikova Zh.I., Novgorodova T.A. 1998b. The importance of individual and social experience for interaction between ants and symbiotic aphids // Doklady RAS. Biological Sciences. Vol.359. P.173-175.

Reznikova Zh.I., Ryabko B.Ya. 1986. Analysis of the language of ants by information-theoretical methods // Problems of Information Transmission. Vol.22. P.245-249.

Reznikova Zh.I., Ryabko B.Ya. 1994. Experimental study of the ants' communication system with the application of the Information Theory approach // Memorabilia Zoologica. Vol.48. P.219-236.

Ryabko B.Ya., Reznikova Zh.I. 1996. Using Shannon entropy and Kolmogorov complexity to study the communicative system and cognitive capacities in ants // Complexity. Vol.2. P.37-42.

Ryabko B.Ya.,Reznikova Zh.I. 2009. The use of ideas of information theory for studying "language" and intelligence in ants // Entropy. Vol.11. P.836-853.

Schmid-Hempel P. 1992. Worker castes and adaptive demography // Journal of Evolutionary Biology. Vol.5. P.1-12.

Sih A., Bell A.M., Johnson J.C., Ziemba R.E. 2004. Behavioral syndromes: an integrative overview // Quarterly Reviews in Biology. Vol.79. P.241-277.

Völkl W., Woodring J., Fischer M., Lorenz M.W., Hoffmann K.H 1999. Ant-aphid mutualisms: the impact of honeydew production and honeydew sugar composition on ant preferences // Oecologia. Vol.118. P.483-491.

Way M.J. 1963. Mutualism between ants and honeydew producing Homoptera // Annual Review of Entomology. Vol.8. P.307344. 